きくなり，なめらかきが失わ机体皘も增加し，これらの影響を防ぐ ためにはスライス幅に対するテーブル移動距離はスライス幅々同 程度が最適䛧であるという結果報告であった，演題20は，広範卧在 精度の高い三次元画像在得るために注大容量のX線管球が望专れ るが，容量が十分でない現状ではノイズの多い画像となるため，自 作ファントム在用いてへリカルスキャンによって得られたオリジ ナル画像在バソコンでイイズ低減処理し三次元表示画像への有効 性を検討したもので，ノイズ処理の効果が十分認められるものであ つた。

C Tのヘリカルスキャン方法が登場してからて〜8 年を迎える 現在に至っても，その性能評価法や撮影方法についての技術的研究 が多くの施設でおこ交われており，手法の確立に今後皆様の研究に 期待したいと思います。

RI (1)

座長 大阪 肇（秋田県成人病医療センター）

21. ${ }^{123}$ I-IMP を用いた超早期画像による局所脳血流量の測定 新潟大学医学部附属病院

大滝広雄·野回栄吉・羽田野政義・長沢 弘・小田野行男

〔目的〕Kuhlらの報告による ${ }^{123}$ J-MP を用いたマイクロスフ エアモデルによる脳血流測定法は IMP 静注後早期(約う外以内)に おいて成立するが時間上ともに洗い出しの影響が無視できなくな ると言われている。尽こでら分後を中心上するう分間収集の超早期 の SPECT 画像より $\gamma \mathrm{CBF}$ 在測定し，從来の方法上比較したので 報告する。

〔結果〕正方形 ROIによる Early 法と Super Early 法の比較で は $\mathrm{y}=0.84 \mathrm{x}+7.43 \mathrm{R}=0.880$ となり，不整形 ROIでは $\mathrm{y}=1.01$ $\mathrm{x}+0.49 \mathrm{R}=0.999$ となり，5分後の画像より $\gamma \mathrm{CBF}$ 算出する Super Early 法保従来の方法乞比較して $\gamma \mathrm{CBF}$ 测定值, 相関係数と も良好で今後高感度ガンマカメラの普及により超早期画像より $\gamma \mathrm{CBF}$ 测定が可能になる。

22. ${ }^{99 M T c-E C D}$ のシリンジ内標撞法に関する検討

石巻赤十字病院

西村章三・渋 孝幸・本村成子・斉藤春夫・北原正和 㨫血流 SPECT 用放射線医菜品としては, 従来 ${ }^{123}$ I-IMP p Tc-HMPAOが用いられていたがIMPは剂型が標識斉み注射液の ため緊急時に対応できず，また HMPAOの標識率は調製直後でも $90 \%$ 程度と低く，経時的に劣化する久点を有していた。これらの久 点在補うべく新しい999Tc-ECDが開発されたＥCDの標識キット

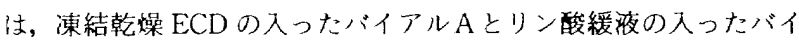
アルBより搆成されており，2 ステッナ法にて調製し，バイアル $\mathrm{B}$ 内で標識反忘を進行させるのが通常である、今回我々は調製操作を 簡略化し注射筒内で標識老行うシリンジ内標識法を考案し検討を 行ったのでその結果を報告する。

\section{3. ${ }^{99 m} \mathrm{Tc} \cdot \mathrm{ECD}$ の撮像開始時間について} 広南病院

$$
\text { つ大友一匡・児玉降一・石倉和彦・勝又三夫 }
$$

脳梗塞严急性期等に奶いて, luxury purfusion を示病態の場 合, ECD と HMPAO, IMPでは異なるイメージを示すことが報告 きれている。この時の ECDの脳内動態をdynamic SCANにて観 察することを目的とした。dynamic SCANは静注直後より1 framel 分にて撮影した。年の結果, ECD は一時的にHMPAO と同 様に高集積となるが徐々に洗い出された。これより，従来静注う分
後に撮影可能といわ机ているが luxury purfusionを示す病態にお いて法，静注10分後から撮影するのが望ましいと思われる。

\section{座長集約}

このセッションはR I 部門の脳に関するもので，Q1)では， ${ }^{123}$ I IMP 在用いての Super-early 法と Early 法の各々で脳血流量を算 出し，比較を行った演題と，(22)では， ${ }^{99 m} \mathrm{~T} \mathrm{C} \cdot \mathrm{ECD}$ の薬剮調製操作を シリンジ内で行って簡略化したシリンジ内標識法の報告, そして(23) はluxury perfusion を示病態での ${ }^{99 \mathrm{~m}} \mathrm{~T}$ c-ECD 静注から SPECT 撮像開始までの時間に関しての検討報告でした, 脳の薬郕として幾 つか市販されていますが，それぞれに長所・短所があり，施設ごと 汇苦心し，使い分けしているものと思わ机ます。会場での討論も非 常に活発で, 菜郕の特徴を生加していく上で有意義なセッションで あったと感じられました。

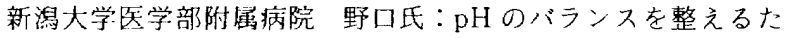
めのB液であるが, シリンジ内で調製する際, 量の違いによる問題 はないですか。(22)の演者：摽識率については検討しましたが, $\mathrm{pH}$ に関しては検討しませんでした。

秋田県立脑血管研究センター 庄司氏：5分後像は収集時間の 問題で，当然ノイズが多く，フィルター処理を行うとなまってしま うと思いますが，何か対策があったら教えて下さい。(23)の演者：全 くその通りでして，只今いろいろと検討して扔ります。

秋田県立脳血管研究センター 住司氏：ECDでは, luxury perfusion を示す病態の場合, Dynamic scanでの Early phaseのみで 著明な集積が認めら饥まず，果たして本当に血流を示しているの か，丰しメーカーの方がいらしたら，教えて下さい。解答なし．

秋田県立脳血管研究センター 蜂谷氏：てんかん発作が検查の 際，持続しているということを脳波などで確認しましたか。(22)の演 者：脳波は行いませんでしたが, 医師が発作中と判断した上で検査 を行いました。

RI (2)

座長 佐藤 博（似北組合総合病院）

24. シンチレーション・プローフ併用による堅機能測定

山形大学医学部附属病院

C鉿木 敏・高橋和榮・加賀勇治

〔目的〕核医学における血中クリアランス法を用いた腎機能测 定は, 腎裁と心時間放射能曲線が必要である。非移植腎は, 胸 部〜腹部の背面にガンマカメラを対向させ心䑏と腎藏の同時観察 が可能で, GFR などを算出できるが, 移植腎は骨盤腔内に位置する ためガンマカメラの視野に入りきらず，1回の検査で心プールの時 間放射能曲線と腎シンチグラムの同時観察はできない。私共は, こ の不都合の解決のためシンチレーション・プローブを併用する方法 在考案し，その妥当性を検討した。

〔結果〕心䑏部にシンチレーション・プローブを併用し心プール の時間放射能曲線を得るシステムにより, 移植腎でも腎機能を定量 的に評価することができた。

25.ファントムによる心筋 SPECT で発生するArtifact の検討

（第 1 報：心筋部の回転中心からの距離による検討）

新潟大学医学部附属病院

C羽田野政義・野口栄吉・大滝広雄・長沢 弘

新潟大学医学部

C木村元政・小田野行男

SPECTによる再構成画像は椂々な画像処理や，複雑な計算過程 